\title{
TRETERA, J. R. - HORÁK, Z. (eds.). Spiritual Care in Public Institutions in Europe. \\ Berlin: Berliner Wissenschafts-Verlag, 2019, 140 s.
}

Anglicky psaná kolektivní monografie Spiritual Care in Public Institutions in Europe, kterou edičně připravili prof. Jiří Rajmund Tretera a doc. Záboj Horák z Právnické fakulty Univerzity Karlovy, představuje publikační výstup ze čtvrtého ročníku mezinárodní konference Pražské rozhovory o vztahu církví a státu, který se odehrál ve dnech 13. až 15. června 2019 na půdě Právnické fakulty Univerzity Karlovy. Publikace, která vychází jako 3. svazek ediční řady Kirche \& Recht Beihefte, nabízí čtenáři unikátní možnost komparace právní úpravy kategoriální pastorace a duchovní péče ve veřejných institucích na úrovni vybraných evropských zemí díky studiím dvanácti autorů z Velké Británie, Francie, Švýcarska, Německa, Rakouska, Polska, Mad’arska, Slovenska a České republiky, které jsou v publikaci obsaženy.

V první kapitole, která slouží jako úvod celé knihy, definuje profesor Tretera samotný pojem duchovní péče ve veřejných institucích, zabývá se jednotlivými oblastmi duchovní péče poskytované v těchto institucích a činností kaplanů a dobrovolníků a zároveň představuje další spoluautory této publikace a jejich odborné zaměření.

Vybraným aspektům pastorační péče poskytované v jednotlivých veřejných institucích v Německu se ve svém prŕspěvku věnuje profesor Gerhard Robbers z Právnické fakulty Trevírské univerzity. V tomto př́spěvku je podrobně analyzován zajímavý duální aspekt právní úpravy pastorační péče ve veřejných institucích, kdy základní garance jsou zakotveny v právních předpisech s celostátní působností v čele se Základním zákonem a konkrétnější úprava je pak obsažena $\mathrm{v}$ partikulárních zemských zákonech a dohodách mezi církvemi a zemskými vládami.

Následná kapitola z pera profesora Marka Hilla QC z Centra pro právo a náboženství Univerzity v Cardiffu je věnována kaplanské službě v Anglii, její historii, tradici a sociologickým aspektům. Zvláštní pozornost je zaměřena na službu kaplanů v ozbrojených silách, zejména pak v Královském letectvu, a pastorační péči v rámci systému Národní zdravotní služby.

V kapitole věnované právní úpravě ve Francii profesor Francis Messner ze Štrasburské univerzity rozebírá organizaci kaplanské služby v tomto laickém státě, která při absenci podrobnější úpravy vychází zejména ze článku 5 odlukového zákona z roku 1905. Profesor Messner dále zkoumá postavení armádních, nemocničních a vězeňských kaplanů v historii a dnes s ohledem na specifickou situaci ve Francii jakožto odlukovém státu.

Profesor Adrian Loretan z Teologické fakulty Univerzity v Lucernu ve svém př́spěvku rovněž reflektuje specifickou situaci ve své zemi a zkoumá právní úpravu duchovní péče 
a kategoriální pastorace ve světle pro Švýcarsko typické přímé demokracie. V příspěvku jsou rovněž popsány základní principy, ze kterých švýcarská právní úprava vychází. V neposlední řadě je rovněž rozebrána roztrrišštěnost právní úpravy kategoriální pastorace a duchovní péče v oblastech zdravotnického systému a státního školství, kde je konkrétní úprava svěřena do pravomocí jednotlivých kantonů, a je dána do kontrastu s úpravou kategoriální pastorace a duchovní péče v oblasti ozbrojených sil, která je zakotvena na federální úrovni.

Profesor Wolfgang Wieshaider působící na Právnických fakultách Vídeňské univerzity a Univerzity Karlovy pak ve své kapitole přibližuje čtenářům právní úpravu v sousedním Rakousku s důrazem na postavení armádních, policejních, nemocničních a vězeňských kaplanů.

Profesor Balász Schanda z Fakulty práva a politických věd Katolické univerzity Petra Pázmánye v Budapešti se ve svém příspěvku věnuje, kromě současnosti, i historickému vývoji kaplanské služby, a na konkrétním příkladu pak dokazuje klíčový význam duchovní péče poskytované v necírkevních institucích, a to i pro osoby, které se v těchto institucích nacházejí a nevyznávají žádnou víru. Kromě duchovní péče poskytované ve státních nemocnicích, věznicích a ozbrojených silách se prŕíspěvek zabývá i duchovní péčí poskytovanou na mezinárodním letišti v Budapešti.

V kapitole věnované Polsku se profesor Piotr Stanisz z Katolické univerzity v Lublinu zaměřuje na rozložení polské společnosti dle př́slušnosti k některé z církví či náboženských společností, historickou tradici kaplanské služby, zakotvení náboženských práv a svobod na ústavní úrovni a z nich vyplývající práva příslušníků ozbrojených sil, hospitalizovaných a osob umístěných ve věznicích, jakož i na konkrétní úpravu kaplanské služby v jednotlivých veřejných institucích.

Autorská dvojice doktorka Michaela Moravčíková a doktor Martin Šabo z Právnické fakulty Trnavské univerzity v Trnavě rozebírají právní úpravu v sousední Slovenské republice zejména s přihlédnutím k mezinárodním smlouvám uzavíraným mezi Slovenskou republikou a Svatým stolcem. Kapitola rovněž vychází z praktických zkušeností doktora Šaba, který působí jako vězeňský kaplan ve věznici v Dubnici nad Váhom.

Poslední dvě kapitoly publikace jsou věnovány vybraným aspektům právní úpravy kategoriální pastorace a poskytování duchovní péče ve veřejných institucích v České republice. V první z nich pojednává docent Damián Němec z Cyrilometodějské teologické fakulty Univerzity Palackého o duchovní péči poskytované ve zdravotnických zařízeních. Rozebírány jsou základní právní předpisy a dohody mezi představiteli církví a státními orgány upravující tuto oblast, faktická situace v českých nemocnicích, činnost nemocničních kaplanů a dobrovolníků působících ve zdravotnických zařízeních, a role České biskupské konference a Ekumenické rady církví.

V úvodu závěrečné kapitoly pak docent Záboj Horák z Právnické fakulty Univerzity Karlovy analyzuje základní principy duchovní péče v České republice a historický vývoj této oblasti před jeho násilným přerušením způsobeným komunistickým pučem v roce 1948 a po jeho obnově po roce 1989. Podrobně je pak v této kapitole popsána nejenom duchovní péče poskytovaná v ozbrojených složkách a ve věznicích, ale i v policejních a hasičských sborech, ve školách, na mezinárodním letišti ve vztahu k obětem trestných činů, teroristických útoků a prrírodních katastrof. 
Publikace představuje mimořádně zdařilou komparaci systémů duchovní péče ve veřejných institucích v mnoha evropských zemích a slouží jako významný zdroj poznání jak pro badatele v oboru konfesního práva, tak pro širokou veřejnost. Kniha, díky tomu, že je psaná anglicky, není určena pouze pro české a slovenské čtenáře, ale dá se předpokládat, že osloví i zahraniční odborníky a přispěje k dalšímu prohloubení vědeckého poznání $\mathrm{v}$ této oblasti.

doi: 10.14712/2464689X.2020.36

Jan Beránek 